\title{
ETNOMATEMATIKA PADA LOPO SUKU BOTI DAN INTEGRASINYA DALAM PEMBELAJARAN MATEMATIKA
}

\author{
Wilfridus Beda Nuba Dosinaeng', Meryani Lakapu²,Yohanes Ovaritus Jagom³, \\ Irmina Veronika Uskono 4 \\ 1,2,3,4 Universitas Katolik Widya Mandira, Jl. Jend. A.Yani No. 50-52, Kupang, Indonesia \\ Email: wilfridusdosinaeng@gmail.com
}

\begin{abstract}
Lopo Boti is a traditional building of the Boti Tribe, one of the opposing tribes on Timor Island, NTT. This building contains high philosophical values and it has an important role in the Boti tribe. This is qualitative research with an ethnographic design that aims to explore mathematical elements contained in lopo Boti. The research design used ethnomathematics design by Alangui which is based on four basic questions namely: where is to look? how was his appearance? what is that? what does it mean?. The Subjects in this research were the Boti Dalam people, one part of the Boti Tribe who still adheres to the Boti tradition in their daily lives. Data were collected through direct observation in the Boti Village and interviews with research subjects. The results showed that the geometrical elements include primitive concepts, the concepts of distance in space, congruence, and surface areas as well as the elements of arithmetic sequences and rows contained in lopo Boti. Based on these elements, some of the mathematical abilities that can be developed in learning mathematics which provided by lopo Boti were the ability to represent, visual-spatial ability, critical thinking ability, ability to investigate, and ability to solve problems.
\end{abstract}

Keywords: Boti tribe, culture, ethnomathematics, lopo, mathematical elements

\section{ABSTRAK}

Lopo Boti adalah sebuah bangunan tradisional milik suku Boti, salah satu suku tertua di Pulau Timor, NTT. Bangunan ini mengandung nilai-nilai filosofis yang tinggi dan berperan penting dalam kehidupan masyarakat suku Boti. Penelitian ini adalah suatu penelitian kualitatif berdesain etnografi yang bertujuan untuk mengeksplorasi unsur-unsur matematis yang terkandung dalam lopo Boti. Desain penelitiannya menggunakan desain etnomatematika oleh Alangui yang didasarkan pada empat pertanyaan dasar yaitu: where is it to look? how is it to look? what is it? what does it mean? Subjek penelitiannya yaitu masyarakat suku Boti, khususnya suku Boti Dalam, salah satu bagian dari suku Boti yang masih memegang teguh tradisi Boti dalam hidup kesehariannya. Data dikumpulkan melalui observasi langsung di desa Boti dan wawancara bersama subjek penelitian. Hasil analisis data menunjukkan bahwa unsur-unsur geometri meliputi unsur-unsur primitif, konsep jarak dalam ruang, kesebangunan, dan luas permukaan, serta unsur-unsur barisan dan deret aritmetika terkandung dalam lopo Boti. Berdasarkan unsur-unsur tersebut maka beberapa kemampuan matematis yang dapat dikembangkan dalam pembelajaran matematika bermediakan lopo Boti yaitu kemampuan merepresentasi, kemampuan visual-spasial, kemampuan berpikir kritis, kemampuan menginvestigasi, dan kemampuan memecahkan masalah.

Kata kunci: Budaya, etnomatematika, lopo, suku boti, unsur-unsur matematis

Dikirim: 22 April 2020; Diterima: 29 Agustus 2020; Dipublikasikan: 30 September 2020

Cara sitasi: Dosinaeng, W. B. N., Lakapu, M., Jagom, Y. O., \& Uskono, I. V. (2020). Etnomatematika pada lopo suku boti dan integrasianya dalam pembelajaran matematika. Teorema: Teori dan Riset Matematika, 5(2), 117-132. 


\section{PENDAHULUAN}

Matematika merupakan pengetahuan universal yang telah menjadi bagian dari hidup keseharian manusia. Sebagai suatu ilmu dan alat, matematika berperan penting dalam dunia pendidikan dan digunakan untuk mengatasi masalah dalam kehidupan sehari-hari (Shanti et al., 2018). Selain dalam kehidupan praktis, matematika juga digunakan dalam mempelajari ilmu-ilmu lainnya seperti sains, teknik, kedokteran, ekonomi, bisnis, perbankan, dan sebagainya. Bebagai teknologi modernpun dihasilkan dan dikembangkan dengan menggunakan matematika.

Perkembangan matematika yang kian pesat dewasa ini tidak terlepas dari latar belakang budaya yang menyertainya. Budaya adalah cara masyarakat berpikir dan cara mereka mengatasi masalah dalam kehidupan sosial (Zaenuri \& Dwidayati, 2018). Matematika telah berkembang dalam budaya masyarakat dunia jauh sebelum masehi. Konsep pengukuran dan luas dalam geometri berasal dari kebiasaan masyarakat Mesir Kuno dalam mendefinisikan kembali batas-batas tanah yang tergerus oleh banjir Sungai Nil (pada sekitar 5000 SM atau 4000 SM hingga 500 SM). Pengetahuan yang muncul dari hasil pengamatan, percobaan, dan perkiraan kemudian dikembangkan menjadi suatu pengetahuan geometri tentang ukuran dan luas. Pengetahuan ini terus berkembang dan tersebar hingga mencapai puncaknya pada Era Euclid (Muhtadi et al., 2017). Perkembangan matematika dewasa ini tidak terlepas dari budaya dan kesepakatan bersama dalam masyarakat. Sebagai contoh, dibandingkan dengan Sistem bilangan Romawi yang tidak memiliki angka nol, sistem nilai tempat desimal pada umumnya menggunakan angka-angka dari Sistem Bilangan Hindu-Arab, 0, 1, 2, 3, 4, 5, 6, 7, 8, 9 sehingga mempermudah dalam penulisan (Zara, 2008). Berkaitan dengan aritmetika, cara-cara berpikir bangsa Timur Tengah dalam melakukan operasi perkalian dan pembagian tertuang dalam Papirus Rhind atau biasa disebut Ahmes yaitu suatu artefak budaya yang berisi instruksi manual tentang cara mempelajari aritmetika dan geometri Bangsa Mesir Kuno (Purnama \& Rohmah, 2018). Ahmes diperkirakan berasal dari tahun 1650 SM, namun ada kemungkinan bahwa dokumen tersebut adalah sebuah salinan dari dokumen lainnya yang dibuat pada sekitar 2000 SM-1800 SM. Berdasarkan jejak-jejak sejarah di atas maka dapat disimpulkan bahwa matematika adalah suatu produk yang dihasilkan oleh budaya.

Pembelajaran matematika yang melibatkan budaya akan membantu para siswa dalam menyadari keterkaitan antara matematika dan budaya. Salah satu cara yang dapat dilakukan yaitu melalui etnomatematika. Konsep etnomatematika pertama kali diperkenalkan oleh D'Ambrosio, seorang matematikawan asal Brasil dengan ruang lingkupnya yaitu analisis pengaruh faktor sosial budaya dalam kegiatan belajar mengajar dan pengembangan matematika (Supriadi et al., 2016). Secara umum, Kusuma (2019) menjelaskan etnomatematika sebagai suatu pengetahuan yang mengaitkan matematika dengan unsur budaya. Secara khusus, hal-hal ini mencakup ide-ide, pemikiran-pemikiran, dan praktik-praktik matematis yang berkembang dalam suatu kelompok budaya, menjadi bagian dalam hidup keseharian, dan dijalankan oleh kelompok budaya tersebut secara turun-temurun (Sulaiman, 2019).

Secara etimologis, istilah etnomatematika berasal dari Bahasa Inggris, ethnomathematics, yang disintesis oleh D'Ambrosio dari Bahasa Yunani ethno, mathema, dan techne yang kemudian berubah menjadi tics. Awalan ethno mengacu pada konteks budaya secara keseluruhan, kata dasar mathema berarti mengetahui, memahami, menjelaskan, dan melakukan kegiatan-kegiatan seperti mengkodekan, mengukur, mengklasifikasi, dan memodelkan, sedangkan akhiran techne berarti teknik (Hariastuti et al., 2019; Rosa \& Orey, 2013; Turmudi, 2017). Jadi, etnomatematika dapat diartikan sebagai teknik untuk memahami, menjelaskan, dan melakukan kegiatan-kegiatan matematis seperti mengkodekan, mengukur, mengklasifikasi, dan memodelkan dalam konteks budaya.

Frase "matematika dalam konteks budaya" perlu diintepretasikan secara dinamis. Istilah etno dalam etnomatematika merujuk pada unsur-unsur budaya seperti ide-ide, cara-cara khusus dalam bernalar dan mengambil keputusan, nilai-nilai dan norma, aktivitas-aktivitas, serta artefakartefak budaya dari suatu kelompok masyarakat yang mengandung unsur-unsur matematis di 
dalamnya. Sedangkan, istilah matematika merujuk pada pengetahuan matematis seperti membilang, mengukur, menghitung, membandingkan, mendesain, mengklasifikasikan, dan sebagainya (D'Ambrosio, 1985; Utami et al., 2019). Dalam sudut pandang ini, etnomatematika dapat dipahami sebagai matematika yang dihasilkan, digunakan, dikembangkan, dan diwariskan dalam kerangka budaya. Etnomatematika menjebatani antara matematika sebagai ilmu pengetahuan dan budaya yang mengandung unsur-unsur matematis di dalamnya (Maryati \& Prahmana, 2019; Yustinaningrum et al., 2018).

Etnomatematika akan menjadikan pembelajaran matematika lebih dekat dengan kehidupan sehari-hari siswa sebab mengaitkan antara matematika dan unsur-unsur budaya masyarakat tempat para siswa tumbuh dan berkembang. Para siswa yang tinggal dan bersekolah di kawasan Boti, Nusa Tenggara Timur (NTT), adalah siswa-siswa yang tumbuh dan berkembang dalam kondisi sosial yang kaya budaya. Kawasan Boti adalah kawasan terpencil yang terletak di Kecamatan Kie, Kabupaten Timor Tengah Selatan (TTS), sekitar $60 \mathrm{~km}$ dari Kota Soe, NTT, dan didiami oleh masyarakat suku Boti yang masih melestarikan budaya tradisionalnya sampai sekarang. Suku ini terbagi atas dua bagian yaitu suku Boti Luar dan suku Boti Dalam. Berbeda dengan suku Boti Luar yang telah mengalami akulturasi budaya, beberapa penelitian sebelumnya menunjukkan bahwa suku Boti Dalam secara konsisten menjaga kelestarian budaya asli Boti dengan meminimalisir pengaruh budaya luar yang masuk (Jayanti, 2015; Ninu et al., 2018; Situmeang, 2013; Suddin, 2017; Suminar, 2018). Salah satu artefak budaya yang masih dijaga dan digunakan sampai sekarang oleh suku Boti Dalam yaitu lopo. Bangunan ini menyimbolkan kaum lelaki suku Boti, berbentuk bangunan tanpa dinding, biasanya terletak di depan rumah, dan berfungsi sebagai tempat pertemuan (Suddin, 2017). Lopo Boti kaya akan nilai-nilai filosofis dan dibangun dengan menggunakan material-material dari dalam kawasan hutan Boti. Nilai-nilai filosofis tersebut menghasilkan kekhasan pada lopo Boti, misalnya badan lopo yang terdiri dari 5 tiang dengan tiang utama yang terletak di bagian tengah dan menyimbolkan Usif Boti. Bentuk ini berbeda dengan bentuk lopo di desa Nusa, kecamatan Amanuban Barat, kabupaten TTS, yang hanya memiliki 4 tiang pada badan lopo. Walaupun letaknya terpencil dan jauh dari perkembangan zaman, namun dengan etnomatematika, unsur-unsur matematis yang terkandung dalam budaya suku Boti dapat digunakan untuk membantu para siswa dalam belajar matematika sebab matematika dipelajari melalui budaya mereka sendiri.

Kekayaan dan kekhasan budaya Boti menjadikannya menarik untuk diteliti. Prasodjo et al. (2015) melakukan penelitian tentang perilaku tradisional dan peningkatan kesehatan masyarakat Boti. Nuban (2017) meneliti tentang hukum adat yang berlaku dalam budaya Boti. Andung \& Nope (2017) meneliti tentang media komunikasi rakyat dalam budaya Boti. Suminar (2018) melakukan penelitian tentang persepsi masyarakat suku Boti terhadap lingkungan hidup. Sandiningtyas \& Wiyono (2018) meneliti tentang bagaimana pendidikan berbasis budaya dilakukan di sekolahsekolah di kawasan Boti. Dari beberapa penelitian yang telah dilakukan tersebut, belum ada yang meneliti secara khusus tentang unsur-unsur matematis yang terdapat dalam budaya Boti dan integrasinya dalam pembelajaran matematika. Padahal dari sisi pembelajaran, etnomatematika dapat menciptakan pembelajaran matematika yang lebih bermakna dan kontekstual (Fajriyah, 2018). Lebih dari itu, pembelajaran matematika berbasis budaya dapat membantu siswa untuk lebih mengenal dan mencintai budayanya sendiri (Dosinaeng, 2017). Untuk dapat mengembangkan pembelajaran tersebut, eksplorasi terhadap unsur-unsur matematis yang terdapat dalam budaya Boti perlu dilakukan. Penelitian ini bertujuan untuk mengeksplorasi unsur-unsur matematis tersebut dan integrasinya dalam pembelajaran matematika. Hasil eksplorasi ini dapat digunakan sebagai acuan bagi para guru dalam mengembangkan pembelajaran matematika bermediakan lopo Boti.

\section{METODE PENELITIAN}

Penelitian etnografi adalah penelitian tentang pola-pola dan perspektif budaya dalam latar alamiahnya (Gay et al., 2012). Tujuan dari penelitian etnografi yaitu menguraikan suatu budaya, baik yang bersifat abstrak seperti pengalaman, kepercayaan, sistem norma, dan sebagainya ataupun 
yang bersifat material seperti artefak-artefak budaya (alat-alat, bangunan, pakaian, dan sebagainya) (Ghony \& Almanshur, 2014). Sejalan dengan tujuan etnografi tersebut, penelitian ini bertujuan untuk mengeksplorasi unsur-unsur matematis yang terdapat pada lopo (salah satu bangunan tradisional) suku Boti. Desain penelitiannya mengacu pada desain studi etnografi oleh Alangui yang didasari pada 4 pertanyaan dasar: (1) where is it to look?; (2) how is it to look?; (3) what is it?; (4) what does it mean? (Alangui, 2010; Utami et al., 2019).

\section{Where is it to look?}

Pertanyaan ini berkaitan dengan objek apa yang akan diamati dan dimana pengamatan dapat dilakukan. Pada tahap ini, berdasarkan studi pendahuluan yang dilakukan tentang budaya suku Boti, peneliti menetapkan lopo khas suku Boti sebagai objek penelitian. Lopo Boti dipilih sebab bersifat khas, dibangun atas dasar filosofis, dan diduga banyak mengandung unsur matematis di dalamnya. Untuk memperoleh data yang akurat maka pengamatan secara langsung terhadap lopo Boti perlu dilakukan di tempat asalnya. Oleh karena itu desa Boti di kecamatan Kie, kabupaten Timor Tengah Selatan terpilih sebagai lokasi penelitian, khususnya di daerah Boti Dalam yang masih tertutup terhadap budaya luar dan memegang teguh tradisi kebudayaan Boti Dalam hidup keseharian masyarakatnya.

\section{How is it to look?}

Setelah objek dan lokasi penelitian ditentukan, investigasi kemudian dilakukan melalui pengamatan langsung dan wawancara mendalam. Pengamatan difokuskan pada unsur-unsur kuantitatif dan keruangan pada lopo Boti. Sedangkan, wawancara dilakukan bersama informan kunci yang mengetahui segala informasi tentang lopo Boti. Informan kunci dalam penelitian ini yaitu Usif Boti (Raja Boti) dan orang-orang yang terlibat langsung dalam budaya Boti khususnya berkaitan dengan lopo Boti.

\section{What is it?}

Alangui (2010) menjelaskan bahwa investigasi objek penelitian dalam etnomatematika difokuskan pada QRS (quantitative, relational, and spatial realities). Hasil investigasi yang diperoleh pada tahap sebelumnya kemudian direduksi, ditampilkan, dan dianalisis untuk memperoleh data tentang realitas kuantitatif, relasional, dan keruangan lopo Boti. Pada tahap ini, unsur-unsur matematis yang terdapat pada lopo Boti diidentifikasi.

\section{What does it mean?}

Setelah teridentifikasi, unsur-unsur matematis yang terdapat dalam lopo suku Boti kemudian dihubungkan dengan matematika sebagai ilmu pengetahuan. Di tahap ini, hubungan antara budaya suku Boti dan matematika sebagai ilmu dijelaskan.

\section{HASIL DAN PEMBAHASAN}

Lopo merupakan salah satu bangunan tradisional yang dimiliki oleh suku Timor, salah satu suku terbesar di NTT. Sebagai bagian dari suku Timor, suku Boti juga memiliki lopo tradisional yang bersifat unik sesuai dengan karakteristik budaya suku Boti. Lopo ini berbentuk mirip dengan Ume Kbubu atau rumah bulat (rumah khas masyarakat TTS) namun dengan atap yang tidak mencapai tanah.

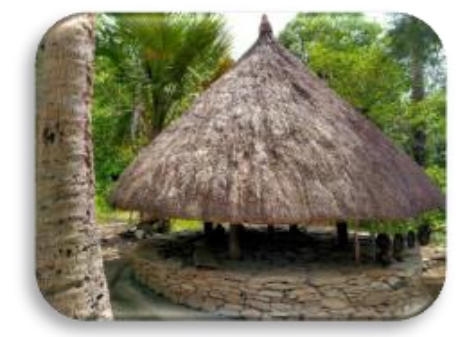

Gambar 1. Lopo di Desa Boti - TTS

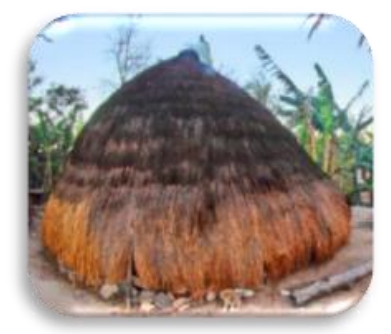

Gambar 2. Ume Kbubu di desa Binaus - TTS (Puspita, Tauho, Nusakawan, Kinasih, 2016) 
Gambar 1 menunjukkan salah satu lopo Boti yang terletak di kawasan Sonaf Boti yaitu tempat Usif (Raja) Boti tinggal. Jika diperhatikan, bentuk lopo tersebut berbeda dengan bentuk Ume Kbubu seperti yang terdapat di Desa Binaus (Gambar 2), TTS. Hal ini disebabkan perbedaan filosofis dan fungsi dari kedua bangunan tradisional tersebut. Ume Kbubu merupakan rumah tradisional yang menyimbolkan kaum perempuan, biasanya terletak di belakang rumah tinggal, berbentuk membulat dari atap sampai tanah, hanya memiliki satu pintu sebagai akses masuk dan keluar, dan berfungsi sebagai dapur atau gudang makanan dan penghangat di saat cuaca dingin tiba (kondisi geografis TTS yang terletak di daerah ketinggian menyebabkan cuaca di sana lebih dingin dibandingkan daerah lainnya di Pulau Timor. Di sisi lain, lopo menyimbolkan kaum lelaki, biasanya terletak di depan rumah, tidak memiliki dinding, dan berfungsi sebagai tempat berkumpul sehingga harus memudahkan akses masuk dan keluar lopo. Di daerah Boti Dalam, lopo berfungsi sebagai tempat berkumpulnya masyarakat suku Boti untuk mendengarkan arahan dari Usif Boti sebagai pemimpin suku Boti atau sekedar berkumpul di saat Neon Tokos (hari kesembilan dalam kalender suku Boti).

\section{Unsur-unsur Matematika pada Lopo}

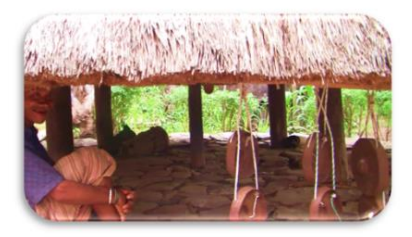

(iii)

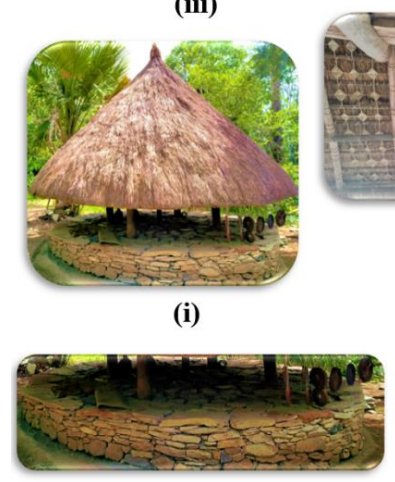

(ii)

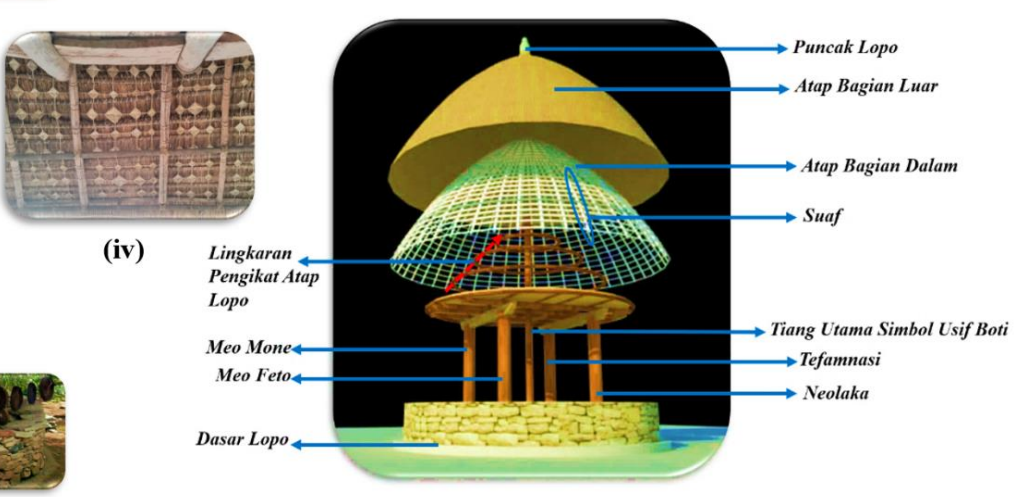

(v)

Gambar 3. Bagian-bagian lopo: (i) Lopo utuh; (ii) Dasar lopo; (iii) Badan lopo; (iv) Suaf pada atap lopo; (v) Model lopo dan bagian-bagiannya

Secara umum lopo terbagi atas tiga bagian utama yaitu bagian dasar, badan, dan atap lopo. Pada Gambar 3 (ii) dapat dilihat bahwa bagian dasar lopo dibentuk dari batu-batu kali yang tersusun melingkar ke atas menyerupai bentuk tabung. Di Gambar 3 (iii) terlihat bahwa badan lopo terdiri dari 5 buah tiang kayu berbentuk tabung yang dipasang tegak lurus dengan dasar lopo sebagai penopang atap. Kelima tiang tersebut terdiri dari 1 tiang utama di bagian tengah yang terhubung sampai puncak lopo dan menyimbolkan Usif Boti dan empat tiang lainnya yang terpasang pada empat penjuru mata angin (mengelilingi tiang utama) dan melambangkan empat panglima Kerajaan Boti yaitu Meo Mone, Meo Feto, Neolaka, dan Tefamnasi yang menjaga Usif Boti. Selanjutnya, pada Gambar 3 (v) dapat dilihat bahwa atap lopo berbentuk selimut kerucut dan terbagi atas dua bagian yaitu bagian dalam yang berbentuk kerangka dari kayu pohon kasuari dan bagian luar yang terbuat dari alang-alang dan diikatkan pada atap lopo bagian dalam. Pada kerangka atap terdapat 25 lingkaran yang terbuat dari pelepah lontar dan tersusun sejajar dari sisi alas sampai puncak atap dengan ukuran diameter yang semakin mengecil. Pada kerangka tersebut juga terdapat suaf (rusuk) yang terbuat dari kayu merah (matani) seperti pada Gambar 3 (iv). Salah satu ujung suaf diikatkan 
pada puncak lopo sedangkan bagian badan sampai ujung yang lainnya diikatkan pada 25 lingkaran dalam jarak-jarak tertentu. Suaf pada setiap lopo harus berjumlah genap, bisa berjumlah $28,30,32$, 34 , dan seterusnya. Suku Boti percaya bahwa jika jumlahnya ganjil maka hal yang buruk akan terjadi pada pemilik lopo. Aturan ini juga diterapkan pada lopo pada Gambar 1 di atas yang memiliki 44 suaf. Selain itu, di bagian loteng lopo juga terdapat 5 lingkaran yang terbuat dari kayu rambat dan berfungsi sebagai pengikat atap pada badan lopo. Khusus untuk lingkaran pertama pada loteng (terletak pada bagian paling bawah), lingkaran ini memiliki area di bagian tengahnya yang difungsikan sebagai tempat menyimpan makanan bagi orang-orang yang sedang berkumpul di lopo.

Bentuk lopo yang membundar telah dikenal oleh masyarakat Boti sejak zaman dahulu. Nenek moyang suku Boti tidak mengenal istilah lingkaran, tabung, ataupun kerucut, namun mereka tanpa sadar telah membangun lopo yang menyerupai gabungan dari bangun-bangun tersebut. Setelah mendirikan bagian badan dan atap lopo, masyarakat Boti menyusun batu-batu mengelilingi badan lopo mulai dari tiang Usif Boti ke arah luar membentuk lingkaran dan tersusun ke atas sehingga menyerupai bentuk tabung. Pengukuranpun dilakukan dengan menggunakan sistem pengukuran tradisional seperti sistem depa.

\section{Unsur-unsur Matematis pada Lopo dan Integrasinya dengan Ilmu Matematika Geometri}

Dari segi bentuk, bagian-bagian lopo banyak mengintegrasikan unsur-unsur geometri. Unsur-unsur tersebut diantaranya unsur-unsur primitif, konsep kesebangunan, jarak dalam ruang, dan luas permukaan.

\section{Unsur-Unsur Primitif}

Istilah primitif ditujukan untuk konsep-konsep sederhana yang mudah dipahami namun susah dibuat batasannya. Titik, garis, dan bidang adalah contoh unsur-unsur primitif dalam geometri yang hubungannya dapat diamati pada lopo. Pada Gambar 4, titik $A$ dan titik $B$ adalah perpotongan dua suaf dengan satu lingkaran pada kerangka atap lopo. Di antara kedua titik tersebut dapat dibentuk garis $l$ yang melalui titik $A$ dan titik $B$, garis $m$ yang melalui titik $B$ dan titik $C$ serta garis $n$ yang melalui titik $A$ dan titik $C$. Ini sesuai aksioma titik dan garis yaitu diantara dua titik dapat dibentuk suatu garis. Selanjutnya, bidang $A B C$ dapat dibentuk oleh ketiga garis tersebut. Ini sesuai dengan teorema garis dan bidang yaitu suatu bidang dapat dibentuk dari tiga titik sembarang (tidak terletak pada satu garis).

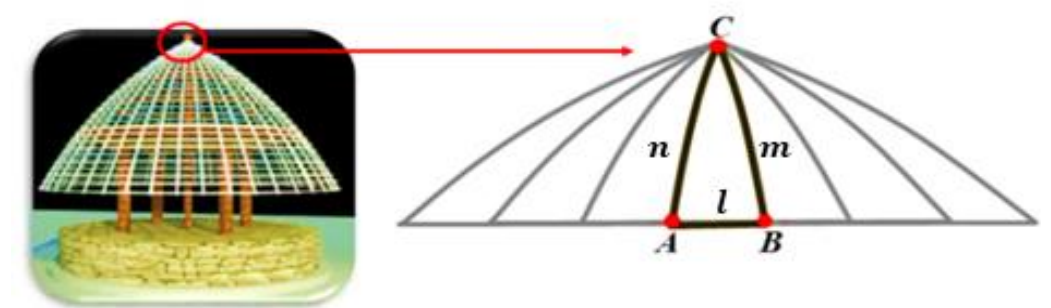

Gambar 4. Geometri titik, garis, dan bidang pada kerangka atap lopo

Selain pada atap, unsur-unsur primitif juga terintegrasi pada badan lopo. Jika 4 tiang panglima diasumsikan sebagai 4 garis yang sejajar dan tegak lurus dasar lopo, maka dapat dibentuk suatu bidang di antara dua tiang panglima (Gambar 5). Berdasarkan asumsi tersebut maka terdapat 6 bidang yang dapat dibentuk yaitu: (i) bidang $A$ di antara garis $g_{1}$ dan $g_{2}$; (ii) bidang $B$ di antara garis $g_{2}$ dan $g_{3}$; (iii) bidang $C$ di antara garis $g_{3}$ dan $g_{4}$; (iv) bidang $D$ di antara garis $g_{4}$ dan $g_{1}$; (v) bidang $M$ di antara $g_{1}$ dan $g_{3}$; dan (vi) bidang $N$ di antara garis $g_{2}$ dan $g_{4}$ (Gambar 5). Selanjutnya, karena bidang $M$ dan bidang $M$ melalui tiang Usif Boti, maka tiang tersebut dapat diasumsikan sebagai garis persekutuan dari bidang $M$ dan bidang $N$. Ini sesuai dengan aksioma garis dan bidang yaitu perpotongan dua bidang yang berbeda adalah sebuah garis. 


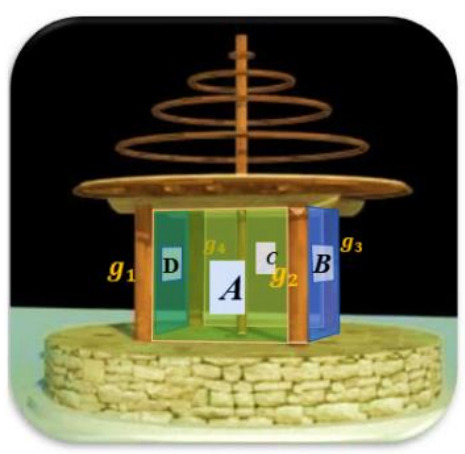

(i)

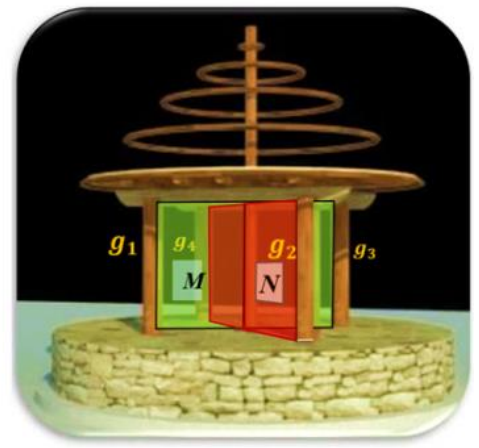

(ii)

Gambar 5. Geometri titik, garis, dan bidang pada badan lopo

Jarak dalam Ruang

Lima lingkaran pengikat atap lopo dipasang tegak lurus terhadap tiang Usif Boti yang terhubung sampai ke puncak lopo. Andaikan ditarik sebuah garis lurus pada diameter setiap lingkaran tersebut yang sejajar satu sama lainnya dan berpotongan dengan tiang Usif Boti, maka suatu bidang cartesius akan terbentuk seperti pada Gambar 6 dengan koordinat-koordinat titik $O, A, B, C, D, E, F, G, H, I$ dan $J$ sesuai dengan hasil pengukuran yang telah dilakukan pada lopo di Gambar 1. Jarak antara titik-titik tersebut mengintegrasikan konsep jarak dua titik dalam bidang. Pada Gambar 6, panjang AC dapat dihitung dengan menggunakan teorema Pythagoras yaitu:

$$
A C=\sqrt{\left(-165-(-220)^{2}+(60-0)^{2}\right.}=81,394
$$

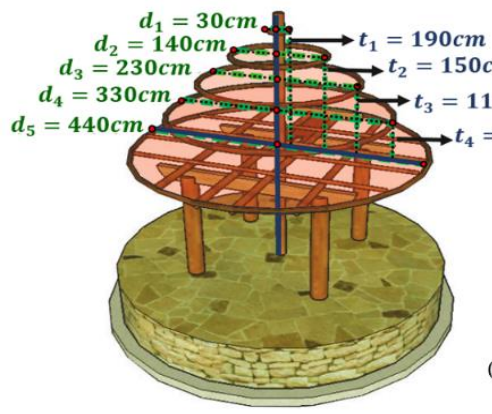

(i)

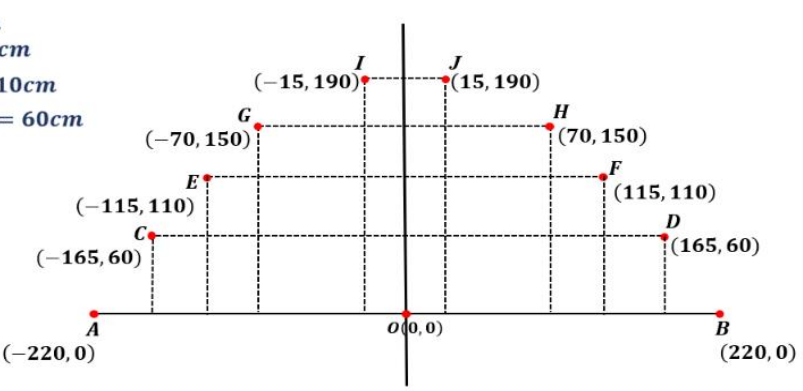

(ii)

Gambar 6. Koordinat cartesius yang dibentuk oleh lingkaran pengikat atap lopo dan tiang usif boti

Sedangkan, pada Gambar 7, panjang PV dapat ditentukan dengan menghitung jarak dua titik dalam ruang yaitu:

$$
\begin{aligned}
& P V=\sqrt{(T P)^{2}+(T V)^{2}}=\sqrt{\left(\sqrt{(O T)^{2}+(O P)^{2}}\right)^{2}+(T V)^{2}} \\
& =\sqrt{\left(0^{2}+165^{2}+0^{2}\right)+\left((-220)^{2}+(0)^{2}+(0)^{2}\right)+\left(0^{2}+0^{2}+60^{2}\right)} \approx 281,469 \mathrm{~cm}
\end{aligned}
$$

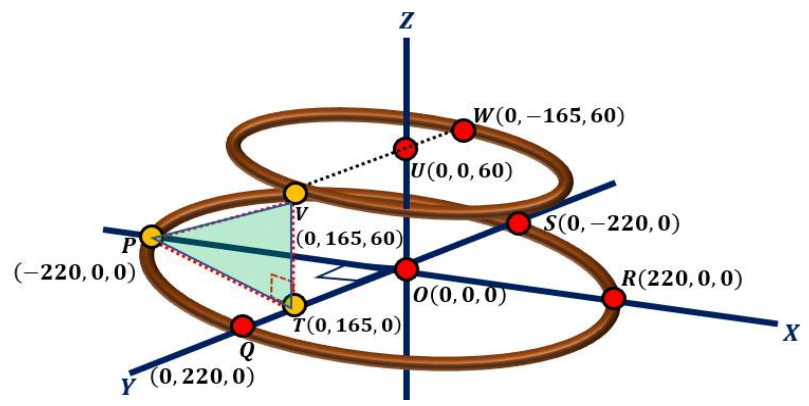

Gambar 7. Contoh hubungan titik dalam ruang yang dibentuk oleh lingkaran-lingkaran pengikat atap lopo 


\section{Kesebangunan}

Selain unsur-unsur primitif, konsep kesebangunan juga terintegrasi pada lopo. Pada bagian kerangka atap, satu ujung dari setiap suaf berpotongan di titik puncak lopo sedangkan bagian badan sampai ujung suaf yang lainnya berpotongan dengan 25 lingkaran yang tersusun sejajar dalam jarak-jarak tertentu. Perpotongan tersebut akan membentuk bangun gabungan juring-juring lingkaran sebagai seperti pada Gambar 8.

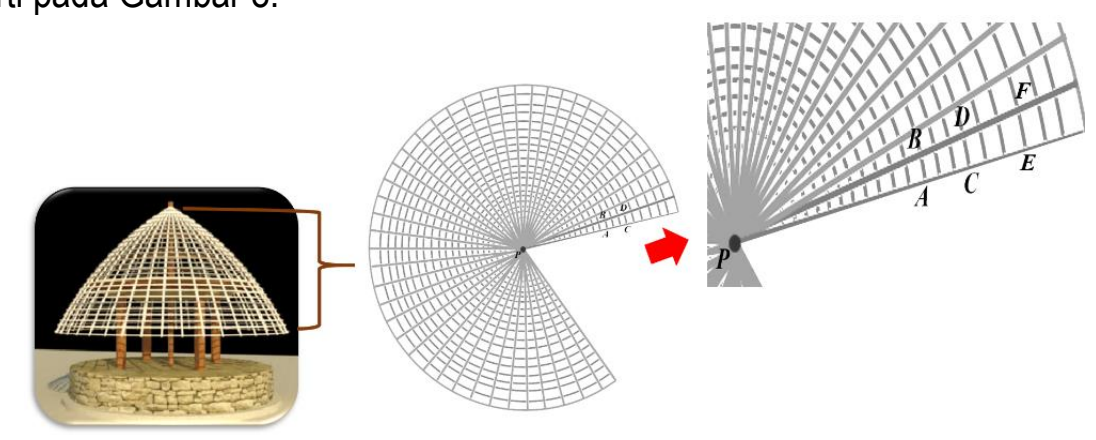

Gambar 8. Kerangka atap lopo

Pada Gambar 8 dapat dilihat bahwa juring $A P B$ sebangun dengan juring $C P D$ sebab $m(\angle A P B)=m(\angle C P D)$ dan $P A: P C=P B: P D$. Begitu pula, juring $C P D$ sebangun dengan juring EPF sebab $m(\angle C P D)=m \angle(E P F)$ dan $P C: P E=P D: P F$. Kedua kesebangunan tersebut kemudian berimplikasi pada $m(\angle A P B)=m \angle(E P F)$ dan $P A: P E=P B: P F$ sehingga juring $A P B$ juga sebangun dengan juring $E P F$. Dengan cara yang sama maka untuk setiap 2 suaf yang berdampingan dan berpotongan dengan 25 lingkaran ada 25 juring sebangun yang terbentuk.

\section{Luas Permukaan}

Lopo mengintegrasikan suatu bangun gabungan sehingga konsep luas permukaan baik pada bidang datar maupun bangun ruang juga terintegrasi pada lopo. Pada Gambar 9 (i) luas permukaan dasar lopo yang berbentuk tabung dapat dihitung dengan menggunakan rumus luas permukaan tabung dikurangi dengan luas alas dan luas area yang ditembusi oleh kelima tiang pada badan lopo. Jika diasumsikan dasar lopo mempunyai jari-jari berukuran $r$, tiang Usif Boti mempunyai jari-jari berukuran $r_{1}$, dan keempat tiang panglima mempunyai ukuran jari-jari yang sama yaitu $r_{2}$ maka diperoleh:

$$
L_{\text {dasar lopo }}=\pi r^{2}-\pi r_{1}^{2}-4 \pi r_{2}^{2}+2 \pi r t=\pi r\left(r-r_{1}-r_{2}+2 t\right)
$$

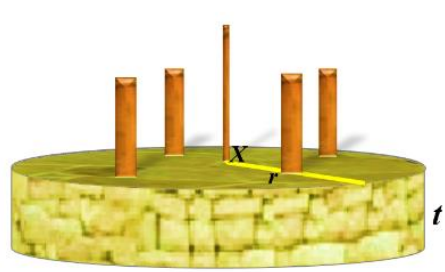

(i)

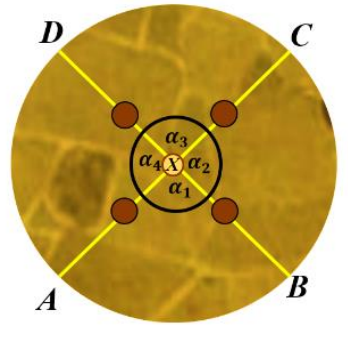

(ii)

Gambar 9. Alas lopo

Di sisi lain, suatu juring lingkaran dapat dibentuk melalui tiang Usif Boti dan dua tiang panglima yang berdampingan sehingga pada sisi atas dasar lopo dapat dibentuk empat juring seperti pada Gambar 9 (ii). Jika besar sudut pusat pada setiap juring diketahui maka empat juring yang terbentuk mengintegrasikan konsep luas lingkaran sebagai penjumlahan dari luas juring-juring penyusunnya sebagai berikut: 
$L=\left(\frac{\alpha_{1}}{360^{\circ}} \times \pi r^{2}\right)+\left(\frac{\alpha_{2}}{360^{\circ}} \times \pi r^{2}\right)+\left(\frac{\alpha_{3}}{360^{\circ}} \times \pi r^{2}\right)+\left(\frac{\alpha_{4}}{360^{\circ}} \times \pi r^{2}\right)=\left(\frac{\alpha_{1}+\alpha_{2}+\alpha_{3}+\alpha_{4}}{360^{\circ}}\right) \times \pi r^{2}=\pi r^{2}$

Selanjutnya, pada badan lopo terdapat 5 tiang berbentuk tabung yang terdiri dari 4 tiang panglima dan 1 tiang Usif Boti yang luas permukaannya dapat dihitung dengan menggunakan rumus luas permukaan tabung. Pada lopo di Gambar 1, Setiap dua tiang panglima memangku satu penopang kerangka atap berbentuk bangun gabungan dari 6 trapesium dan 4 jajargenjang (Gambar 10). Jika diperhatikan, setiap tiang panglima tidak berbentuk tabung utuh, namun ada bagian yang dihilangkan pada sisi atas untuk meletakkan penopang kerangka atap. Pada Gambar 10, jika diasumsikan keempat tiang panglima berbentuk empat tabung kongruen, $r$ adalah jari-jari alas tabung, $A B=\frac{1}{m} K_{a}=x$ dengan $K_{a}$ adalah keliling lingkaran alas tabung dan $m>1, m \in \mathbb{N}$,

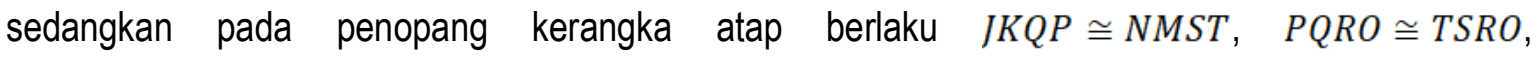
$I J K L \cong I N M L$, dan $I J P O \cong K L R Q \cong L M S R \cong I N T O$, maka luas bangun gabungan dua tiang panglima dan satu penopang kerangka atap lopo ditentukan sebagai berikut:

$$
L=2\left(\pi r t_{1}-x t_{2}\right)+(P Q+J K) t_{3}+4 K L \cdot t_{4}+(O R+T S) t_{5}+(I L+N M) t_{6}-4(B C \cdot C G)
$$

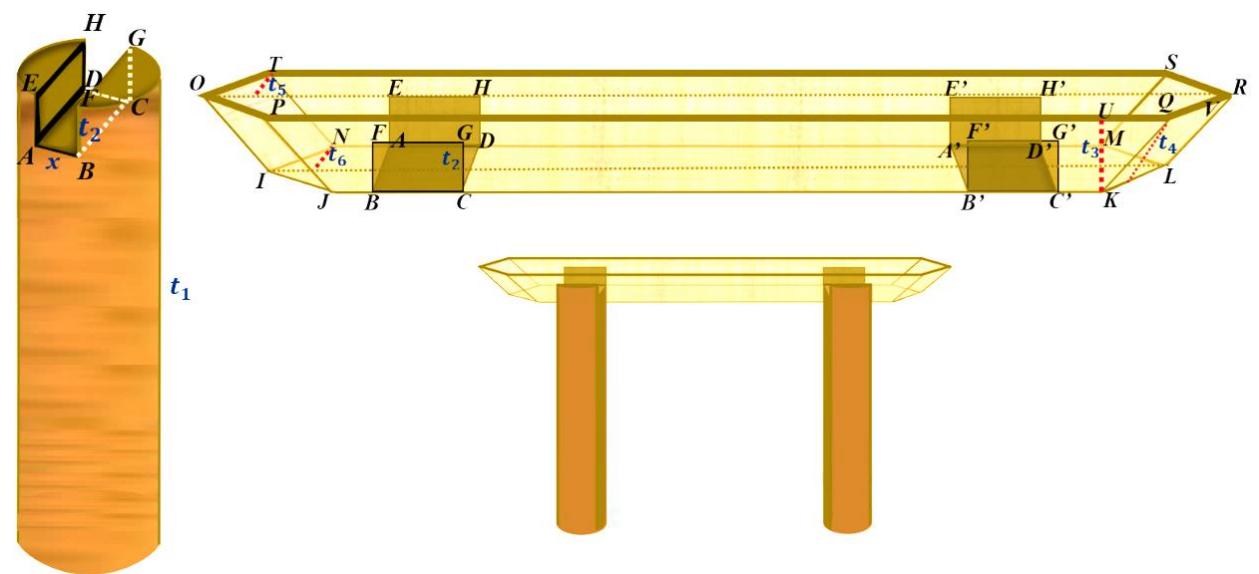

Gambar 10. Badan lopo

Pada bagian atap lopo terintegrasi konsep kerucut yang luas permukaannya dapat dihitung dengan menggunakan rumus luas selimut kerucut. Pada Gambar 11 dapat dilihat bahwa atap lopo bagian luar lebih panjang $m$ satuan dibandingkan dengan kerangka atap lopo di bagian dalam. Suaf adalah garis pelukis $(s)$ sedangkan busur $A B$ adalah keliling alas dari kerangka atap lopo tersebut. Dengan demikian, luas atap lopo bagian dalam dapat ditentukan sebagai berikut.

$$
\begin{aligned}
L_{\text {Atap bag.luar }}= & \pi r_{\text {atap luar }} \times(s+m)=\pi\left(\frac{\text { Panjang tali busur } A^{\prime} B^{\prime}}{2 \pi}\right)(s+m) \\
& =\frac{1}{2} \text { keliling alas atap bagian luar } \times(s+m)
\end{aligned}
$$

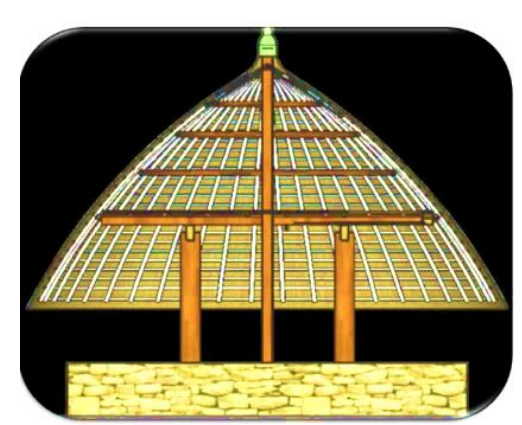

(i)

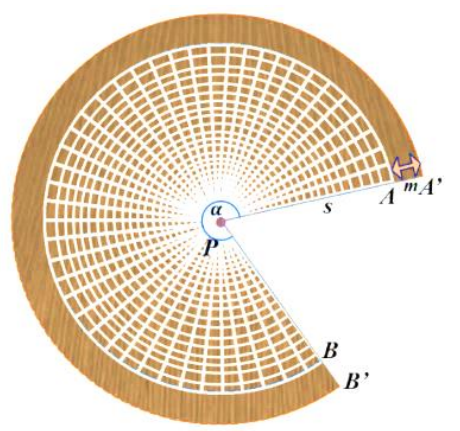

(ii)

Gambar 11. Atap lopo sebagai selimut kerucut 
Pembuktian Rumus Luas Lingkaran

Lingkaran kayu pada loteng lopo yang berfungsi sebagai pengikat atap dapat dipandang sebagai suatu bangun segi- $n$ yang terbentuk dari $n$ buah segitiga sama kaki dengan $r$ sebagai kakikakinya seperti pada Gambar 12. Dengan menghitung luas segitiga-segitiga penyusunnya, luas bangun segi- $n$ tersebut dapat ditentukan yaitu $L=n \cdot \frac{1}{2} r^{2} \operatorname{Sin} \theta$.

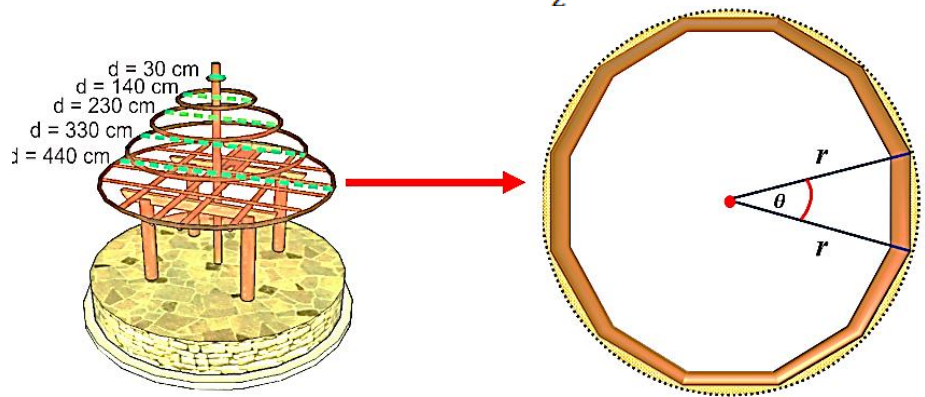

Gambar 12. Lingkaran pengikat atap pada loteng lopo

Pada Gambar 12 terlihat bahwa jika $n$ semakin mendekati tak hingga, maka bangun segi-n tersebut semakin menyerupai lingkaran. Dengan menggunakan limit tak hingga diperoleh:

$$
\begin{aligned}
\lim _{n \rightarrow \infty} n \cdot \frac{1}{2} r^{2} \operatorname{Sin} \theta & =\lim _{n \rightarrow \infty} \frac{\frac{\pi}{n}}{\frac{\pi}{n}} n \cdot \frac{1}{2} r^{2} \operatorname{Sin} \theta \\
= & \lim _{n \rightarrow \infty} \frac{\frac{\pi}{n}}{\frac{\pi}{n}} n \cdot \frac{1}{2} r^{2} \operatorname{Sin} \theta=\lim _{n \rightarrow \infty} \cdot \frac{\pi}{\frac{2 \pi}{n}} r^{2} \operatorname{Sin} \theta=\lim _{n \rightarrow \infty} \cdot \frac{\pi}{\theta} r^{2} \operatorname{Sin} \theta \\
& =\pi r^{2} \lim _{n \rightarrow \infty} \cdot \frac{\operatorname{Sin} \theta}{\theta}=\pi r^{2}(1)=\pi r^{2}
\end{aligned}
$$

\section{Barisan dan Deret}

Pada kerangka atap lopo terdapat 25 lingkaran yang tersusun sejajar secara vertikal dengan panjang diameter setiap lingkarannya seperti pada Gambar 13.

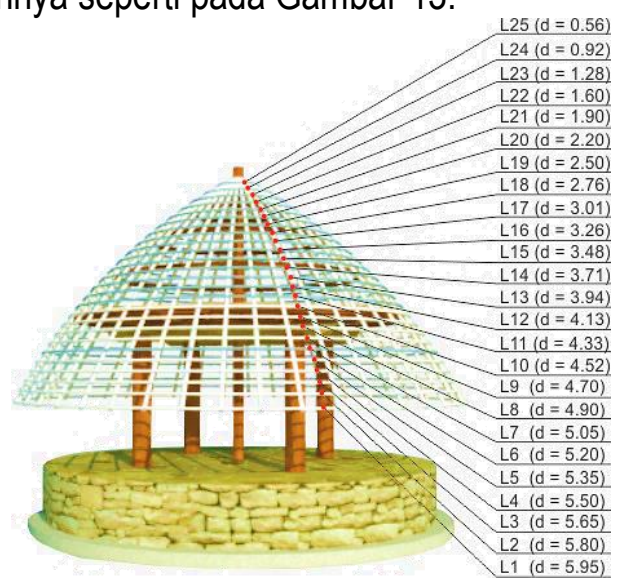

Gambar 13. Lingkaran-lingkaran pada kerangka atap lopo beserta ukuran diameternya

Pada Gambar 13 di atas dapat dilihat bahwa ukuran diameter 25 lingkaran pada kerangka atap membentuk suatu pola bilangan untuk lingkaran pertama sampai lingkaran kedelapan. Pola tersebut merupakan suatu barisan aritmetika tingkat satu dengan nilai selisih tetap atau nilai bedanya yaitu $(-0.15)$ (Gambar 14$)$.

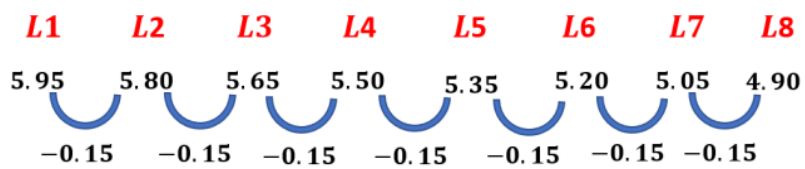

Gambar 14. Ukuran diameter lingkaran pertama sampai lingkaran kedelapan beserta selisihnya 
Berdasarkan informasi pada Gambar 14 tersebut maka nilai suku ke-n dari barisan tersebut dapat ditentukan dengan menggunakan rumus $U_{n}=5.95-0.15(n-1)$ dengan $n=1,2,3,4,5,6,7,8$. Selanjutnya dapat dibentuk suatu deret aritmetika yang dinyatakan dengan:

$$
S_{n}=-0.075 n^{2}+6.025 n, \quad n=1,2,3,4,5,6,7,8
$$

Selain pada kerangka atap, konsep baris dan deret juga terintegrasi pada 5 ikatan atap pada loteng lopo yang berbentuk lingkaran dan tersusun sejajar secara vertikal dengan panjang diameter setiap lingkarannya seperti pada Gambar 12 di atas. Berdasarkan hasil pengukuran pada lopo, diameter lingkaran pertama sampai diameter lingkaran keempat dapat ditulis sebagai barisan aritmetika tingkat dua dengan selisih tetap atau beda pada barisan bilangan tingkat dua tersebut yaitu $(-10)$ (Gambar 15).

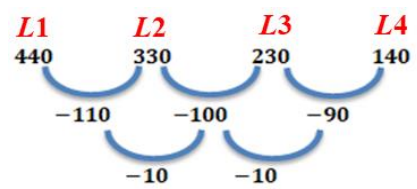

Gambar 15. Ukuran diameter lingkaran pertama sampai lingkaran keempat beserta selisihnya

Berdasarkan informasi pada Gambar 15 tersebut maka nilai suku ke- $n$ dari barisan tersebut dapat ditentukan dengan menggunakan rumus $U_{n}=5 n^{2}-125 n+560$ dengan $n=1,2,3,4$.

Selanjutnya dapat dibentuk suatu deret aritmetika yang dinyatakan dengan:

$$
S_{n}=\frac{1}{6} n\left(10 n^{2}-360 n+2990\right), \quad n=1,2,3,4
$$

\section{Unsur-unsur Matematika pada Lopo dan Kemampuan Matematika}

Unsur-unsur matematis yang ada pada lopo dapat digunakan oleh para guru untuk mengembangkan kemampuan-kemampuan matematis siswa. Beberapa kemampuan matematis yang dapat dikembangkan dalam pembelajaran matematika berbasiskan unsur-unsur matematis pada lopo diantaranya:

\section{Kemampuan Representasi}

Representasi adalah ungkapan ide-ide matematis, baik itu dalam bentuk tulisan, gambar, simbol, grafik, dan sebagainya sebagai alat untuk mengeksplorasi masalah atau konsep (Anwar et al., 2016). Ketika siswa belajar matematika melalui pengamatan pada lopo, merekapun secara tidak langsung belajar mengembangkan kemampuan representasinya. Kemampuan ini mereka gunakan untuk mengubah hasil pengamatan mereka pada lopo ke dalam dalam bentuk tulisan, gambar, atau simbol-simbol yang dapat membantu mereka dalam melakukan perhitungan atau memecahkan masalah-masalah matematis yang berkaitan dengan lopo.

\section{Kemampuan Visual-Spasial}

Kemampuan visual-spasial adalah kemampuan seseorang dalam membayangkan suatu objek atau ruang, memodelkannya secara mental di dalam pikiran, melakukan manuver atau operasi pada model mental tersebut, kemudian menggunakannya di dunia nyata (Fadilah \& Afifah, 2014; Rosidah, 2014). Kemampuan ini merupakan salah satu kemampuan matematis yang dapat dikembangkan melalui pembelajaran geometri. Membayangkan dua tiang panglima sebagai dua garis yang sejajar dan membentuk suatu bidang di antara kedua garis tersebut, atau membayangkan kerangka atap lopo sebagai suatu selimut kerucut dan menghitung luas permukaannya berdasarkan ukuran-ukuran panjang yang diketahui akan membantu para siswa dalam mengembangkan kemampuan ini. 


\section{Kemampuan Berpikir Kritis}

Salah satu bagian dari kemampuan berpikir kritis yaitu kemampuan menganalisis masalah. Kemampuan ini diperlukan dalam mengidentifikasi hubungan antara masalah yang dihadapi dengan konsep matematis sehingga dapat dirancang suatu model yang tepat untuk menyelesaikan masalah (Dosinaeng, 2019). Ketika menentukan luas bidang yang dibentuk oleh titik puncak dan dua suaf pada kerangka atap lopo, diperlukan suatu kemampuan berpikir kritis untuk menyadari bahwa bangun yang dibentuk tersebut adalah suatu juring lingkaran.

\section{Kemampuan Menginvestigasi}

Investigasi adalah suatu proses mencari atau menyelidiki yang dapat dilakukan oleh seseorang/sekelompok siswa untuk memecahkan masalah yang dihadapi (Ningsih, 2019). Sebagai suatu proses, investigasi meliputi proses spesialisasi, pembuatan konjektur, justifikasi, dan generalisasi (Kaur et al., 2009). Kemampuan ini diperlukan oleh siswa dalam menentukan rumus penjumlahan suku ke- $n$ dengan $n$ adalah ukuran diameter lingkaran pertama sampai lingkaran kedelapan pada kerangka atap lopo (dari bawah ke atas). Pada tahap spesialisasi, mereka perlu menentukan selisih panjang diameter lingkaran-lingkaran yang berdampingan untuk mendapatkan nilai beda. Selanjutnya, berdasarkan beberapa nilai diameter yang diketahui dan nilai beda, konjektur dihasilkan dalam bentuk suatu pola sementara. Pola tersebut kemudian perlu dibuktikan kebenarannya pada tahap justifikasi. Jika terbukti benar, maka generalisasi dapat dilakukan mengenai rumus penjumlahan suku ke- $n$ dengan $n$ adalah ukuran diameter lingkaran pertama sampai lingkaran kedelapan pada kerangka atap lopo.

\section{Kemampuan Memecahkan Masalah}

Tujuan utama dalam pembelajaran matematika berbasis pemecahan masalah adalah melatih para siswa untuk mampu mengembangkan kemampuannya dalam memecahkan masalahmasalah dalam dunia nyata (Gurat, 2018). Untuk melatih kemampuan itu, soal-soal yang diberikan pada umumnya berupa soal-soal non rutin yang tidak dapat diselesaikan hanya dengan menerapkan rumus semata. Menentukan luas permukaan dari bangun gabungan dua tiang panglima yang berbentuk tabung dan satu penopang atap yang berbentuk limas segiempat akan memberikan pengalaman yang berbeda bagi siswa dalam bekerja dengan konsep luas sebab mereka perlu mengamati secara seksama bentuk dari bangun gabungan tersebut untuk memahaminya, menyusun rencana penyelesaiannya berdasarkan hasil pengamatannya, menghitung luas permukaan berdasarkan rencana yang telah disusun, dan memeriksa kembali guna memastikan bahwa hasil yang mereka peroleh sudah benar secara matematis.

\section{KESIMPULAN}

Suku Boti merupakan salah satu suku tertua di Pulau Timor, NTT yang masih memegang teguh tradisi budayanya. Salah satu aspek dalam budaya suku Boti yang menjadi bagian dalam hidup keseharian masyarakatnya yaitu lopo Boti. Lopo Boti merupakan tempat berkumpulnya masyarakat suku Boti untuk mendengarkan arahan dari Usif Boti atau sekedar berkumpul pada waktu Neon Tokos (hari kesembilan dalam kalender tradisional suku Boti). Melalui etnomatematika, unsur-unsur matematika yang terkandung dalam lopo Boti dieksplorasi. Hasil analisis menunjukkan bahwa lopo Boti banyak mengandung unsur-unsur geometri serta barisan dan deret. Berdasarkan eksplorasi yang dilakukan, unsur-unsur geometri dalam lopo Boti meliputi unsur-unsur primitif, konsep jarak dalam ruang, kesebangunan, dan luas permukaan. Sedangkan, unsur-unsur barisan dan deret meliputi unsur-unsur barisan dan deret aritmetika yang terkandung dalam bagian loteng dan kerangka atap lopo Boti. Berdasarkan unsur-unsur tersebut maka beberapa kemampuan matematis yang dapat dikembangkan dalam pembelajaran matematika bermediakan lopo Boti yaitu kemampuan merepresentasi, kemampuan visual-spasial, kemampuan berpikir kritis, kemampuan menginvestigasi, dan kemampuan memecahkan masalah. Hasil temuan dalam penelitian ini masih bersifat umum pada 
eksplorasi unsur-unsur matematis dan belum dispesifikkan secara lebih mendalam pada bagaimana unsur-unsur ini digunakan dalam pembelajaran matematika. Namun, hasil temuan dalam penelitian ini dapat digunakan sebagai dasar untuk melakukan penelitian selanjutnya yaitu pengembangan pembelajaran matematika berbasis etnomatematika budaya suku Boti.

\section{REKOMENDASI}

Berdasarkan temuan yang diperoleh, peneliti menyarankan kepada para guru matematika untuk dapat mengembangkan pembelajaran matematika bermediakan lopo Boti. Media ini dapat digunakan dalam mempelajari aksioma-aksioma geometri, jarak dalam ruang, kesebangunan, luas permukaan bidang datar dan bangun ruang, serta barisan dan deret aritmetika. Selain mampu meningkatkan pengetahuan dan kemampuan matematis siswa, pembelajaran ini akan membantu para siswa untuk lebih mengenal dan mencintai budayanya sendiri.

\section{UCAPAN TERIMAKASIH}

Peneliti mengucapkan terima kasih kepada pihak Kemenristekdikti, Direktorat Jenderal Penguatan Riset dan Pengembangan yang telah membiayai penelitian ini. Ucapan terima kasih juga disampaikan kepada pihak Universitas Katolik Widya Mandira di Kupang yang telah mendukung kelancaran penelitian ini hingga selesai.

\section{DAFTAR PUSTAKA}

Alangui, W. V. (2010). Stone walls and water flows: interrogating cultural practice and mathematics (The University of Auckland). Retrieved from https://researchspace.auckland.ac.nz/handle/2292/5732.

Andung, P., \& Nope, H. (2017). Media rakyat sebagai media komunikasi pembangunan masyarakat suku boti. Jurnal IImu Komunikasi, 14(2), 277-292. https://doi.org/10.24002/jik.v14i2.870.

Anwar, R. B., Yuwono, I., As'ari, A. R., Sisworo, \& Rahmawati, D. (2016). Mathematical representation by students in building relational understanding on concepts of area and perimeter of rectangle. Educational Research and Reviews, 11(21), 2002-2008. https://doi.org/10.5897/err2016.2813.

D'Ambrosio, U. (1985). Ethnomathematics and its place in the history and pedagogy of mathematics. For the Learning of Mathematics-an International Journal of Mathematics Education, 5(1), 4448.

Dosinaeng, W. B. N. (2017). Analisis pemikiran matematis dalam permainan tradisional masyarakat lamaholot. Prosiding Seminar Nasional Etnomatnesia, 491-498.

Dosinaeng, W. B. N. (2019). Analysis of students' higher order thinking skills in solving basic combinatorics problems. Math Didactic: Jurnal Pendidikan Matematika, 5(2), 133-147. https://doi.org/10.33654/math.v5i2.611.

Fadilah, E., \& Afifah, D. S. N. (2014). Kecerdasan visual-spasial siswa smp dalam memahami bangun ruang ditinjau dari perbedaan kemampuan matematika. Jurnal Pendidikan Matematika, STKIP PGRI Sidoarjo, 2(2), 151-158.

Fajriyah, E. (2018). Peran etnomatematika terkait konsep matematika dalam mendukung literasi. Prisma, Prosiding Seminar Nasional Matematika, 1, 114-119. 
Gay, L., Mills, G. E., \& Airasian, P. (2012). Educational research, competencies for analysis and applications. New Jersey: Pearson Education, Inc.

Ghony, M. D., \& Almanshur, F. (2014). Metodologi penelitian kualitatif. Jogjakarta: Ar-Ruzz Media.

Gurat, M. G. (2018). Mathematical problem-solving strategies among. ERIES Journal, 11(3), 53-64. https://doi.org/10.7160/eriesj.2018.110302.Introduction.

Hariastuti, R. M., Budiarto, M. T., \& Manuharawati, M. (2019). From culture to classroom: study ethnomathematics in house of using banyuwangi. International Journal of Trends in Mathematics Education Research, 2(2), 76. https://doi.org/10.33122/ijtmer.v2i2.60.

Jayanti, I. G. N. (2015). Budaya boti dan eksistensinya di era kekinian. Jurnal Penelitian Sejarah dan Nilai Tradisional, 22(1).

Kaur, B., Har, Y. B., \& Kapur, M. (2009). Mathematical problem solving. Singapore: World Scientific Publishing Co.Pte.Ltd.

Kusuma, D. A. (2019). Peningkatan komunikasi matematis siswa menggunakan pembelajaran kontekstual berbasis etnomatematika dengan penerapan mozart effect (studi eksperimen terhadap siswa sekolah menengah pertama). Teorema: Teori dan Riset Matematika, 4(1), 6574. https://doi.org/10.25157/teorema.v4i1.1954.

Maryati \& Prahmana, R. C. I. (2019). Ethnomathematics: exploration of the muntuk community. International Journal of Scientific and Technology Research, 8(6), 47-49.

Muhtadi, D., Sukiran, Warsito, \& Prahmana, R. C. I. (2017). Sundanese ethnomathematics: mathematical activities in estimating, measuring, and making patterns. Journal on Mathematics Education, 8(2), 185-198. https://doi.org/http://dx.doi.org/10.22342/jme.8.2.4055.

Ningsih, F. (2019). Pengaruh model pembelajaran group investigation terhadap kemampuan pemecahan masalah siswa kelas viii mtsn kabupaten kerinci. Jurnal Cendekia: Jurnal Pendidikan Matematika, 3(2), 351-362. https://doi.org/10.31004/cendekia.v3i2.118

Ninu, J. J. A. S., Rihadi, S., \& Tirtahusada, K. (2018). Gambaran penanganan ibu hamil dan bersalin pada suku boti dalam kecamatan ki'e, kabupaten timor tengah selatan. Jumal Widya Medika Surabaya, 4(1), 25-30.

Nuban, D. K. E. R., Hartiwiningsih, \& Jamin, M. (2017). The legal aspects of boti's tribe: "when the national law is not required". International Journal of Business, Economics and Law, 13(4), 130-137.

Prasodjo, R., Musadad, D. A., Muhidin, S., Pardosi, J., \& Silalahi, M. (2015). Advocate program for healthy traditional houses, ume kbubu, in a timor community: preserving traditional behavior and promoting improved health outcomes. Journal of Health Communication, 20(S1), 10-19. https://doi.org/10.1080/10810730.2015.1013390

Purnama, W., \& Rohmah, M. S. (2018). Sejarah dan filsafat matematika (edisi revisi 2018). Direktorat Jenderal Guru dan Tenaga Kependidikan, Kementerian Pendidikan dan Kebudayaan. 
Puspita, D., Tauho, K. D., Nusawakan, A. W., \& Kinasih, A. (2016). Fungsi ume kbubu dan aktivitas penghuninya saat cuaca dingin di desa binaus, Kabupaten Timor Tengah Selatan-Nusa Tenggara Timur. KRITIS, Jurnal Studi Pembangunan Interdisiplin, 25(1), 1-9.

Rosa, M., \& Orey, D. C. (2013). Ethnomodelling as a research lens on ethnomathematics and modelling. Journal of Urban Mathematics Education, 6(2), 117-127. https://doi.org/10.1007/978-94-007-6540-5_10.

Rosidah, L. (2014). Peningkatan kecerdasan visual spasial anak usia dini melalui permainan maze. Jurnal Pendidikan Usia Dini, 8(2), 281-290.

Sandiningtyas, H., \& Wiyono, B. B. (2018). Pendidikan berbasis budaya lokal suku boti: studi kasus di sdn-smpn satu atap oefau desa boti nusa tenggara timur. IImu Pendidikan: Jurnal Kajian Teori dan Praktik Kependidikan, 3(1), 77-82. https://doi.org/10.17977/um027v3i12018p077.

Shanti, W. N., Sholihah, D. A., \& Martyanti, A. (2018). Meningkatkan kemampuan berpikir kritis melalui problem posing. LITERASI (Jurnal IImu Pendidikan), 8(1), 48. https://doi.org/10.21927/literasi.2017.8(1).48-58

Situmeang, V. S. N. (2013). Ume kbubu: Household granary and food security in timor tengah selatan. University of Oregon.

Suddin, S. (2017). Resources of boti village (timor island) for the ecotourism development. Journal of Indonesian Tourism and Development Studies, 5(2), 107-112. https://doi.org/10.21776/ub.jitode.2017.005.02.06.

Sulaiman, H. (2019). Aktivitas matematika berbasis budaya pada masyarakat pesisir di pasar ikan gebang kabupaten cirebon. MaPan, 7(1), 61-73. https://doi.org/10.24252/mapan.2019v7n1a5.

Suminar, E. (2018). Persepsi suku boti terhadap lingkungan hidup. Ensains Journal, 1(2), 89. https://doi.org/10.31848/ensains.v1i2.100.

Supriadi, Arisetyawan, A., \& Tiurlina. (2016). Mengintegrasikan pembelajaran matematika berbasis budaya banten pada pendirian sd laboratorium upi kampus serang. Mimbar Sekolah Dasar, 3(1), 1-18. https://doi.org/10.17509/mimbar-sd.v3i1.2510.

Turmudi. (2017). Kajian etnomatematika: belajar matematika dengan melibatkan unsur budaya. Prosiding Seminar Nasional Etnomatnesia, 38-53.

Utami, N. W., Sayuti, S. A., \& Jailani. (2019). Math and mate in javanese primbon: ethnomathematics study. Journal on Mathematics Education, 10(3), 341-356. https://doi.org/10.22342/jme.10.3.7611.341-356.

Yustinaningrum, B., Nurliana, \& Rahmadhani, E. (2018). The ethnomathematics: exploration of gayo tribe local wisdom related to mathematics education. Journal of Physics: Conference Series, 1088. https://doi.org/10.1088/1742-6596/1088/1/012061. 
-132 Teorema: Teori dan Riset Matematika, 5(2), 132-132, September 2020

Zaenuri, \& Dwidayati, N. (2018). Menggali etnomatematika: matematika sebagai produk budaya. Prisma, Prosiding Seminar Nasional Matematika, 1, 471-476. Retrieved from https://journal.unnes.ac.id/sju/index.php/prismal

Zara, T. (2008). Babylonian Mathematics: A brief study of some aspects of babylonian mathematics. Liberty University. 